\title{
Higher education in nursing: the faculty work process in different institutional contexts
}

\author{
EDUCAÇÃO SUPERIOR EM ENFERMAGEM: O PROCESSO DE TRABALHO DOCENTE EM \\ DIFERENTES CONTEXTOS INSTITUCIONAIS
}

\author{
EDUCACIÓN SUPERIOR EN ENFERMERÍA: EL PROCESO DE TRABAJO DOCENTE EN \\ DISTINTOS MARCOS INSTITUCIONALES
}

\author{
Valéria Marli Leonello', Maria Amélia de Campos Oliveira²
}

\begin{abstract}
Objective: To analyze the characteristics of faculty work in nursing higher education. Method: An exploratory qualitative study with a theoretical-methodological framework of dialectical and historical materialism. The faculty work process was adopted as the analytical category, grounded on conceptions of work and professionalism. Semi-structured interviews were conducted with 24 faculty members from three higher education institutions in the city of São Paulo, classified according to the typology of institutional contexts. Results: The faculty members at these higher education institutions are a heterogeneous group, under different working conditions. Intensification and precarious conditions of the faculty work is common to all three contexts, although there are important distinctions in the practices related to teaching, research and extension. Conclusion: Faculty professionalization can be the starting point for analyzing and coping with such a distinct reality of faculty work and practice.
\end{abstract}

\section{DESCRIPTORS}

Education higher

Education nursing

Faculty Nursing

\section{RESUMO}

Objetivo: Analisar as características do trabalho docente no ensino superior em Enfermagem. Método: Estudo exploratório e qualitativo cujo referencial teóricometodológico foi o materialismo histórico e dialético. Como categoria analítica, adotou-se o processo de trabalho docente, ancorado nas concepções de trabalho e profissionalidade. Foram realizadas entrevistas semiestruturadas com 24 docentes de três instituições de ensino superior da cidade de São Paulo, classificadas segundo a tipologia de contextos institucionais. Resultados: Revelaram que os docentes dessas instituições de ensino superior constituem um grupo heterogêneo, submetido a diferentes condições de trabalho. A intensificação e a precarização do trabaIho docente é comum aos três contextos, embora haja distinções importantes nas práticas didáticas relacionadas a ensino, pesquisa e extensão. Conclusão: A profissionalização docente pode ser o ponto de partida para a análise e o enfrentamento de uma realidade tão distinta de trabalho e prática docente.

\section{DESCRITORES \\ Educação superior \\ Educação em enfermagem \\ Docentes de enfermagem}

\section{RESUMEN}

Objetivo: Analizar las características del trabajo docente en la educación superior en Enfermería. Método: Estudio exploratorio y cualitativo cuyo marco de referencia teórico-metodológico fue el materialismo histórico y dialético. Como categoría analítica, se adoptó el proceso de trabajo docente, anclado en las concepciones de trabajo y profesionalidad. Se realizaron entrevistas semiestructuradas con 24 docentes de tres instituciones de educación superior de la ciudad de São Paulo, clasificadas según la tipología de contextos institucionales. Resultados: Se revelaron que los docentes de dichas instituciones de educación superior constituyen un grupo heterogéneo, sometido a distintas condiciones laborales. La intensificación y la precarización del trabajo docente son comunes a los tres marcos, aunque existan diferencias importantes en las prácticas didácticas relacionadas con la enseñanza, la investigación y la extensión. Conclusión: La profesionalización docente puede ser el punto de partida para el análisis y el enfrentamiento de una realidad tan distinta de trabajo y práctica docente.

\section{DESCRIPTORES \\ Educación superior \\ Educación en enfermería \\ Docentes de Enfermería \\ Docencia}

${ }^{1}$ PhD Professor, Professional Orientation Department, School of Nursing, São Paulo University, São Paulo, SP, Brazil. ${ }^{2}$ Full Professor, Department of Nursing in Collective Health, School of Nursing, São Paulo University, São Paulo, SP, Brazil.

$\begin{aligned} \text { Rev Esc Enferm USP } & \text { Received: 13/05/2014 } \\ 2014 ; \text { 48(6):1091-9 } & \text { Approved: 18/09/2014 }\end{aligned}$




\section{INTRODUCTION}

Higher education has a strategic position in the socioeconomic development of a country, given its relationship with the training and qualification of a workforce able to operationalize and implement modernization and improvement processes within the society.

In Brazil, higher education has undergone a number of changes over the last two decades, especially after the promulgation of the Lei de Diretrizes e Bases (Law of Directives and Bases, LDB) in 1996, with the diversification and expansion at all levels and modalities deserving note ${ }^{(1)}$. The LDB determined that higher education can be conducted at public or private higher educational institutions (HEIs), which may be universities, colleges or university centers ${ }^{(2)}$.

These changes resulted in a strong expansion of the system, mainly in the private sector, with the support of government policies. As a consequence of the adopted policy, the growth was marked by unequal geographic distribution of courses, concentrated in the southeastern and southern regions.

Studies show that the scenario of higher education expansion and diversification directly affects faculty work, which confronts the consequences of policy changes established in Brazil. Therefore, confronting this reality and work process are distinctly and directly related to the institutional format in which the faculty members are located ${ }^{(3-4)}$.

In health education, particularly in nursing education, there is a gap in the scientific literature on the subject. In general, studies address the characteristics of faculty work in limited institutional contexts, according to the administrative or academic nature of the HEls, not taking as a starting point the faculty work process in different contexts, but rather using specific approaches, such as quality of life ${ }^{(5)}$ and job satisfaction ${ }^{(6)}$.

According to the Marxian conception ${ }^{(7)}$, work is conceived as a process, a transformation of a given object by means of the intentional action of an agent, who, in order to achieve this purpose, employs material or intellectual instruments.

With regard to the nursing faculty work process, the agents are faculty members in nursing higher education, in other words, whose working object is another human being, the nursing student, more specifically his knowledge, skills and attitudes. The instruments represent the entire arsenal, physical or intellectual, which faculty members use to intervene/act with this individual.

Considering the general context of higher education in the country, in nursing education in particular, and in order to contribute to the understanding of this multifaceted reality of faculty work in different institutional contexts, this study sought to answer the following questions: What is the work process of nursing faculty members in different institutional contexts? Under what conditions is it performed? What are the practices of these faculty members?

Therefore, the object of this study is the nursing faculty work process in different institutional contexts, and its objective is to analyze the work process of nursing faculty members in HEls, in the city of São Paulo.

\section{METHOD}

Dialectical and historical materialism was adopted as the theoretical and methodological framework, and the faculty work process was adopted as an analytical category, grounded in conceptions of work $^{(7)}$ and professionalism ${ }^{(8)}$. When seeking to understand the main aspects of the different levels in which faculty work and professionalism operate, the historical materialist and dialectical analysis performs an articulated movement within the dynamics of social reality.

An assumption is made that faculty work is a way to intervene in the social reality; therefore, it is a social practice. As such, it can only be understood and comprehended if its relationship with the institutional context in which it is inserted is analyzed ${ }^{(3)}$. Professionalism, in turn, refers to what is specific to the faculty action, referring to the behaviors, skills, attitudes and values of being a faculty member ${ }^{(8)}$.

Considering work and professionalism as analytical categories implies an unveiling of the heterogeneity of faculty work in institutional formats existing in the current scenario of higher education in Brazil, assuming that this scenario determines different working conditions, practices and professional development.

In order to classify the HEls, a typology of institutional contexts ${ }^{(9)}$ was used, which classifies higher education institutions into three major types: business contexts, presenting a small proportion of doctorally prepared faculty members and those faculty members with full-time contracts; regional contexts, which have a small proportion of doctorally prepared faculty members and a high proportion of full-time faculty members; and academic contexts, with a high proportion of full-time or exclusive dedication of doctorally prepared faculty members. The data required for the classification were obtained through a request to the Instituto Nacional de Estudos e Pesquisas Educacionais Anísio Teixeira (Anísio Teixeira National Institute for Educational Studies, NIEE) and the classification of the contexts is shown in Table 1.

Table 1 - Distribution of higher education institutions with nursing courses in the state of São Paulo, according to the typology of institutional contexts - São Paulo, 2010

\begin{tabular}{lcc}
\hline Institutional contexts & $\mathbf{N}$ & $\mathbf{\%}$ \\
\hline Academic & 5 & 4.5 \\
Business & 108 & 94.5 \\
Not classified by the typology & 1 & 1 \\
Regional & 0 & 0 \\
\hline Total & $\mathbf{1 1 4}$ & $\mathbf{1 0 0}$ \\
\hline
\end{tabular}


Of the total of 114 HEls with nursing courses in the state of São Paulo in 2010, five (4.5\%) were public universities, and all were classified as academic contexts, which have a high proportion of full-time or exclusive dedication of doctorally prepared faculty members. However, most (108 HEls, 94.5\%) were classified as business contexts, with a small proportion of doctorally prepared faculty members and full-time contracts. No HEI was classified as a regional context. One institution (1.0\%) did not fit in any of the contexts provided by the typology, because of the high proportion of doctorally prepared faculty members and low proportion of tenured faculty members. Because it had characteristics of both of these two contexts, it was classified as a mixed context: a high proportion of doctorally prepared faculty members, characteristic of academic contexts, and a high proportion of part-time faculty members, a characteristic of business contexts.

After classification, three HEls were selected through convenience sampling, one in each context. Because these institutions allowed the researchers to meet the faculty members, semi-structured interviews were conducted with 24 faculty members: nine from the business context, seven from the academic context, and eight from the mixed context. For the interviews, a script was constructed with objective questions for the characteristics of subjects, and guiding questions to achieve the research objectives. In the characterization step, there were eight questions that addressed faculty member titles, the year in which they began to work in the institution, work regimen, type of contract, work in other institutions, and weekly workload. In the next step, the subjects were asked to talk about their daily faculty work, identifying difficulties, facilities and challenges of teaching in their institutional context.

The research project was approved by the Ethics Committee of the School of Nursing, São Paulo University (Process \#876/2009). The HEls were invited by the nursing course coordinators, who authorized the study. All the nursing faculty members were invited through an invitation letter sent via email. Those who agreed to participate were informed about the study objectives and signed a consent form. Faculty members with different backgrounds, titles, and work regimens were interviewed.

The empirical material was submitted to the technique of discourse analysis ${ }^{(10)}$, which enabled the construction of a set of themes which, in turn, were gathered into empirical categories, arranged according to the nested practices system $^{(8)}$, adapted to this study. In the nested practices system, there is a set of interconnected and nested practices that characterize faculty work.

The results were organized into two main sets of practices: didactic and organizational. Organizational practices refer to the aspects of the structure of the organizational context that reflect on the teaching work, such as, for example, the career plan, work regimen, and institutional infrastructure. The didactic practices refer to the set of aspects related to the daily work of faculty members in different contexts, related, for example, to teaching, research and extension (Figure 1).

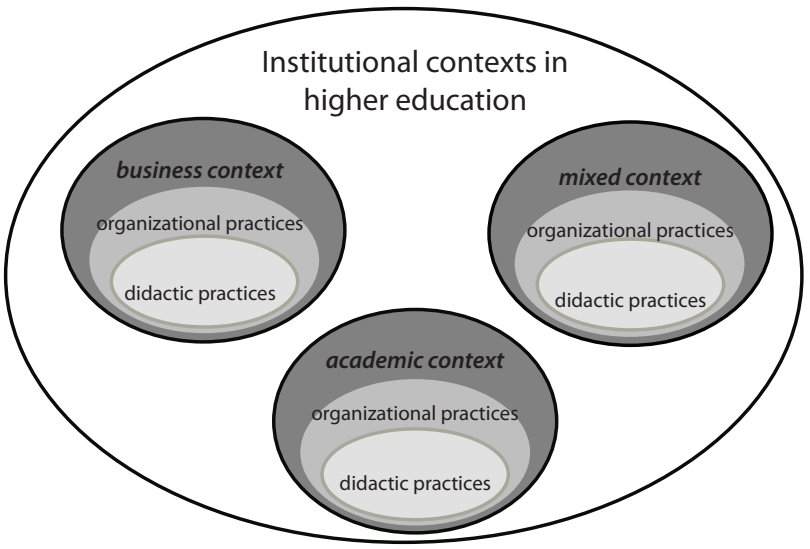

Figure 1 - Representation of the nested practices system ${ }^{(8)}$ adapted to the higher education system.

\section{RESULTS}

In all three contexts, business, mixed and academic, results showed that there is a process of intensification and precarious conditions of faculty member work that impacts on organizational and didactic practices, but with important distinctions in different contexts.

\section{Business context}

With regard to didactic practices, the faculty members in the business context state that their work is primarily directed towards undergraduate classroom teaching, with little integration into administrative, research, extension and graduate teaching activities.

Research activities were not included in faculty member work, therefore, they were not paid. They were performed sporadically in undergraduate education, in course completion studies, and scientific initiation. Extension activities were also sporadic and were not considered part of faculty member work, and therefore were unpaid. Although they had these difficulties in research and extension, the faculty members recognized them as activities that enhanced the quality of education.

The faculty members also faced difficulties related to the profile of the students, who had already been in the labor market, namely, they are student-workers, arriving to the classroom already tired. The challenges concern, for example, the choice of teaching strategies and appropriate assessment of these students.

With regard to organizational practices, the career plan, although formal, is not effectively operated. Regarding the work system, they cited financial instability because the payment is made per hour/class, so the faculty salary is
Higher education in nursing: the faculty work process in different institutional contexts Leonello VM, Oliveira MAC 
dependent on the number of classes/disciplines assigned to them every six months, and there may be changes according to the number of classes each semester. The faculty members in this context had other jobs, some in health care, to complement the salary and ensure financial stability.

Insufficient institutional infrastructure - with scarce material resources and inadequate facilities - was identified as an aspect that hindered faculty work. Communication difficulties between the professors and the administrative structure were also mentioned. However, in this $\mathrm{HEl}$, the coordination of the nursing area offered support, dialogue, respect, autonomy and freedom to faculty members. That allowed professors, for example, to exclusively teach disciplines in their area of interest, which, according to the interviewees, does not always occur at HEls linked to institutional contexts with business characteristics.

\section{Mixed context}

With regard to teaching practices, faculty members' work had some aspects of the business context, mixed with others from the academic context. The work was primarily aimed at undergraduate teaching, but there was an institutional effort to conduct graduate research activities. With regard to the theory-practice relationship, the faculty who taught the theory also accompanied the students into the practical teaching conducted in the internship, unlike the business context in which the faculty members who taught the theory were not necessarily linked to the clinical practice.

Regarding the students' profile, according to the faculty members, the initial selection was more accurate and tuition had a higher value compared to the business environment. There were fewer students per class, with better social integration and less learning difficulties. The faculty members felt that they taught a more select group, with differentiated income and level of instruction. This profile, with an institutional policy of small class sizes, facilitates the teaching practice, making teaching more individualized for the student and more satisfying for the faculty.

The main difficulties and challenges of the faculty work in the mixed context were also about undergraduate teaching, especially in practical teaching in clinical practice, considered by the subjects as a generator of physical and mental strain, given the responsibility to monitor students, manage tensions and reach consensus between teaching and caregiving activities in the fields of practice.

Regarding research activities, although hired as parttime faculty members, they conducted research activities due to an institutional requirement, and they disseminated their findings in publications and paper presentations at events. They mentioned that sometimes there was insufficient time to conduct such activities, which led them to perform them outside of working hours. As in the business context, the research activity was also focused on undergraduate education. Extension activities, seldom mentioned, were sporadic and occasional, through courses, events and presentations of students' work.

As for the organizational practices, there was a career plan that followed some institutional criteria (publication, title, time on the job), although it was mentioned that the salary was not compatible with the workload. The labor regimen was predominantly partial and offered some stability against the hourly regimen, characteristic of the business environment.

Despite these difficulties, the faculty members shared the perception that the HEl valued the quality of education, aiming not only at profit, but at the quality of education of its students. They exemplified this fact by citing the good acceptance of graduates in the labor market in the area.

\section{Academic context}

In this context, concerning didactic practices, faculty member work focused on research and administrative activities, and on graduate teaching. However, according to some subjects, there was a large institutional effort to accomplish curricular reorientation of undergraduate education. For the faculty members interviewed, the academic context overvalued administrative and research activities at the expense of undergraduate teaching and extension activities, which were considered undervalued.

In relation to the student profile, there was no mention of great difficulties or challenges to teaching. The difficulties and challenges were related to the need to promote active student participation and to facing resistance from many faculty members, who valued research over teaching. There were also difficulties in developing practical teaching in the clinical field, given the unpredictability of the actions, due to the complex reality of the services, which created insecurity.

Regarding research activities, a great concern and even anxiety was reported by the faculty members to achieve institutional goals of scientific production and publication, with the value of quantity over quality of the articles being mentioned; competitiveness among peers for research funding; publishing in reputable journals in the field; difficulty managing funded projects, with intense activity reporting and accountability to funding agencies; and, the need for an international curriculum, which required work in collaboration with research groups from foreign institutions.

In graduate teaching, according to the subjects, both internal and external assessments directed faculty participation to research and the advising of masters and doctoral students, and the faculty members that were not part of this group felt less valued institutionally. Another relevant aspect of this context was noted in remarks by the faculty members that other areas of knowledge were more renowned and valued than nursing.

The faculty members also stated that the extension activities were subsumed into research and inclusion of faculty members in administrative positions. Since they believed 
in the potential of extension, in conjunction with teaching and research, they mentioned that this was undervalued within the institutional context, which was expressed by the low weight assigned to it in faculty evaluation.

Regarding organizational practices, the full-time work regimen prevailed, with exclusive dedication, in which the faculty profession was explicit and the criteria for advancement was institutionally validated. With regard to the administrative activities, the main complaint was that they consumed a substantial part of the work, due to the bureaucracy in institutional management processes that led to more work.

Faculty autonomy, characteristic of this context, was identified as a generator of great responsibility, related to the difficulty in establishing rules and consensus among the other professional colleagues. It was unanimous among the respondents that the context gives financial stability and the career is institutionally formalized and ensured, although some report a discrepancy between the work performed and the remuneration received.

In summary, faculty work within the three contexts showed similar features, for example, lack of time to perform the different activities and the need for improved organizational infrastructure, according to the expectations and needs of the work covered in each context.

In the business and mixed contexts, healthcare experience in nursing was seen as an important aspect of faculty practice, being a highly valued differential by students and faculty members themselves. In these contexts, some faculty members mentioned the need for a second job for wage supplementation. In the academic context, and to some extent in the mixed context, given the institutional value for research, the faculty members reported feeling pressured to achieve institutional goals of academic productivity.

\section{DISCUSSION}

The analysis of faculty work in different institutional contexts enabled the construction of four major themes of analysis, also arranged according to the organizational and didactic practices, ${ }^{(8)}$ and adapted for this study (Figure 2).

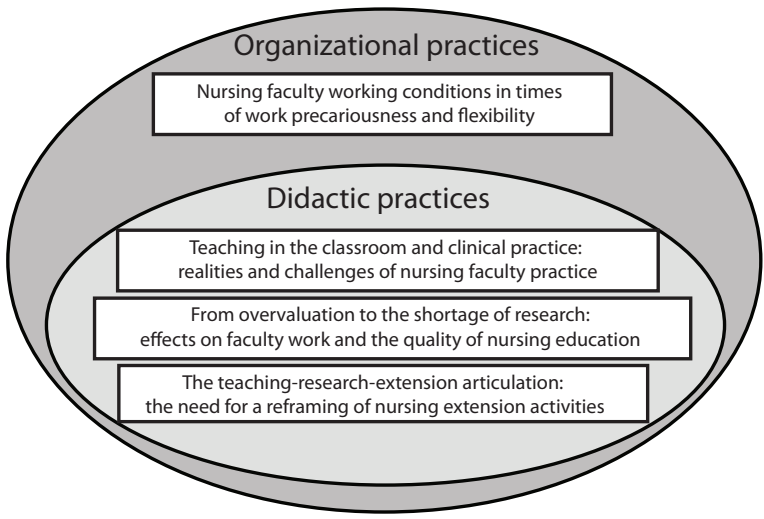

Figure 2 - Analysis themes according to the nested practices system

\section{Organizational practices}

Nursing faculty working conditions in times of work precariousness and flexibility

The precariousness and flexibility of faculty work manifested itself in different ways in different contexts, and the main aspects observed were related to the work regimen, career, and constraints in structural, material and human infrastructure.

These aspects indicate the new configuration of the working relationships established in the states that adopt neoliberalism as a political-economic basis, where unemployment and dispossession of historically constructed labor rights are seen increasingly. In this reconfiguration, a new profile of employee arises, increasingly flexible to perform multitasking, proactive and aware of his/her need for constant updating and training in the face of demands from the labor market ${ }^{(11-12)}$.

In the case of faculty work, especially in nursing, this profile is expressed in work overload, intensification of tasks, and self-penalization for not achieving the many front lines. Even in contexts in which the form of hiring is more stable, faculty members complain about the intensification of activities and little time to perform them ${ }^{(13)}$.

When contracts are unstable, faculty members accumulate jobs in teaching or health care to maintain a reasonable level of financial stability, overloading themselves with activities and often surpassing the 40 hour-week established by labor legislation. A market relationship is established between the work performed by the professor and the HEls, which purchase the work, making it increasingly precarious, through precarious contracts and financially unstable work regimens ${ }^{(14)}$.

The international scenario also shows signs of reduced quality of the faculty work force in higher education. A study conducted in Australia in 2011 showed that, although faculty members felt motivated and considered their careers rewarding, the increased number of students, not accompanied by new faculty positons, has increased their workload ${ }^{(15)}$.

\section{Didactic practices}

\section{Teaching in the classroom and clinical practice: realities} and challenges of the nursing faculty practice

The challenges are reflected in the didactic practice of faculty members that develop teaching, research and extension in different ways, depending on the institutional context. In the theoretical and clinical practice teaching, the challenges range from lack of practical training in the field, in the business context, to the mental and physical wear from this activity, given the unpredictability of the actions in the fields of clinical practice in mixed and academic contexts.
Higher education in nursing: the faculty work process in different institutional contexts Leonello VM, Oliveira MAC 
Studies show that the clinical practice overwhelms the faculty due to the accumulation of activities, such as prior contact with health professionals, recognizing clinical practice and its rules and routines, supervision of students, and concern about the care of the service user ${ }^{(16)}$. The faculty feels so responsible for activities that can be seen as a catalyst for different demands encountered in the field, taking on more responsibilities.

Although exhausting, clinical teaching is deemed necessary to promote student contact with the reality of health services and the health problems of the assisted population. The unpredictability in practice settings, although generating stress, is seen as an opportunity for student and faculty members to exercise listening to the needs of users of health services, respecting the decisions of the people around them ${ }^{(17)}$.

Regarding the students' profile, mentioned in the corporate context as an aspect that complicates the choice of teaching strategies and assessment, the results support a study about the trajectory of nursing courses in the period from 1991-2004, which identified that most students in higher nursing education were already integrated into the labor market. This double work was also an important characteristic of nursing students, mostly from private schools, where working students predominate ${ }^{(18)}$.

Another characteristic is related to the social integration of the students who come from families where the level of parental education is medium. This fact, coupled with the fact that they attended elementary and secondary education in public schools, deserves attention from nursing courses, which must seek diversified strategies in order to promote student learning. A nursing study showed that deficiency in the theoretical basis of the newly admitted students in higher education has become an obstacle to the conduct of the teaching-learning process and therefore to faculty practice ${ }^{(19)}$.

According to the National Education Forum 2013, Brazil still has to face the challenge of making quality, obligatory secondary education universal. This challenge certainly will result in improvements in the quality of higher education ${ }^{(20)}$.

This reality is not unique to Brazil. In the United States, the report from the National Center for Public Policy in Higher Education, in partnership with the National Center for Higher Education Management Systems, identifies the need to improve the quality of secondary education to ensure the best future conditions for access and retention to future professionals ${ }^{(21)}$.

In addition to the characteristics already mentioned, there is a large number of students per class, which, in the business context, for example, is quite variable, which also can hinder faculty work. It is interesting to note that this movement clearly reflects the increase in enrollment in higher education, especially since the 1990s.
The availability of nursing courses grew by $340 \%$ in the period between 1991-2004, a strong growth in the private sector, as is the case of many institutions in the business context ${ }^{(18)}$. The growth has a direct impact on faculty practice: the higher the number of students, the more challenging the pedagogical work. In the mixed context in which the students' profile is different, with a more rigorous initial selection and the highest monthly value as compared to the business environment, there are few students per class, with better social integration and minor learning difficulties. In the academic context, the faculty members did not mention the student's profile, because the students go through a rigorous entrance exam, to devote to a full-time course.

This distinction in the students' profile in different contexts shows that students' access to higher education has also changed after the LDB. The legislation gives freedom to the HEls to formulate entrance exams, which results in easy admission of students with different profiles ${ }^{(22)}$.

Another aspect present in business contexts is the lack of preparation for teaching, with few opportunities to participate in professionalization processes, more evident in the academic context.

Brazilian researchers warn about the fact that most of the stricto sensu graduate faculty training programs do not prepare faculty members for teaching, stressing that training for research does not equate to pedagogical training ${ }^{(3)}$.

Internationally, since 2004, the European Trade Union Committee for Education recommends three great areas for priority actions for faculty training: improving the quality of initial training, recruitment and retention of qualified faculty members, and ensuring that professional development is a right of faculty members and is part of their work process ${ }^{(23)}$.

\section{From overvaluation to the shortage of research: effects on faculty work and the quality of nursing education}

In the academic context, research activity is considered to be the focus of faculty work, the extent to which faculty assessments value research activity production more than undergraduate teaching and extension.

The institutional assessment, in turn, follows external parameters such as the Coordenadoria de Aperfeiçoamento de Pessoal de Nível Superior (Coordination of Improvement of Higher Education Personnel - CAPES), in that faculty work is mainly measured by: time spent on research activities, expressed by the number of articles published in journals indexed with high Qualis (impact factors); research projects funded by funding agencies; graduate teaching activities; and also, the number of masters and doctoral advisees ${ }^{(24)}$.

The phenomenon is called academic productivity, in which the faculty member is considered productive if he/ she has a significant amount of products, such as advisees, 
projects, publications, patents, among others. These aspects lead to increased competitiveness among peers, the professional isolation of faculty members in their research group and, often, alienation at work ${ }^{(25-26)}$.

This concern has also been implicated in a global context, according to the report from the 2013 European Union Study Group on the Modernization of Higher Education, which recommends that the preponderance of research in relation to teaching in the definition of academic merit needs to be revised ${ }^{(27)}$.

On the other hand, there are institutional contexts in which faculty work in research activity is scarce. In mixed and business contexts, research is seen only as a mandatory activity for the training of students, limited to the completion of course work. Research activities not articulated in this work are scarce. Nonetheless, faculty members feel that the mixed context should develop research, although they are hired on a part-time basis, with the workload directed strongly toward classroom teaching. Teachers in the business environment, in turn, develop a research activity, voluntarily, outside of work hours. Sometimes, the research activity in the form of completion of course work is offered in a discipline, and a faculty member is assigned to this activity and the amount paid by the hour/class is assigned by the discipline.

Therefore, with regard to research activities, it is seen that faculty work is conditioned to the actual conditions provided by the institutional format, such as work regimen, for example, which directs the work for this activity. In this study, the research activity in faculty work transitioned from overvaluation in the academic context, to an institutional development effort in the mixed context, to the scarcity of this activity in the business context.

From the perspective of faculty members, the overvaluation of research generates overhead. The institutional requirement of research, even if limited to graduate teaching, if not combined with a consistent work regimen, also overwhelms and intensifies faculty work. The lack of institutional requirement for the exercise of that activity, in turn, has consequences on faculty professionalization. In fact, both forms of conceiving research exert effects on the quality of education provided.

Being a recognized researcher, such as in the academic context, does not necessarily guarantee an excellent pedagogical performance. It is necessary to put research at the service of the faculty practice itself, causing teachers to reframe their practice, to review, contextualize and confront it with the conditioning and determining aspects of their work.

\section{The teaching-research-extension articulation: the need for a reframing of nursing extension activities}

Regarding extension, in all the contexts analyzed, these activities are occasional, sporadic, sometimes not provided as part of the teaching activities, or else institutionally devalued. Even in the academic context in which it is planned as part of the faculty activities, it is subsumed under the administrative and research activities.

In the business context, the extension activities are mentioned little by faculty members. Some even say that they are not developed, while others cite its episodic nature. As the labor regimen, in this context, is per hour/lesson, extension activities are not an institutional requirement.

In the mixed context, extension is understood as activities performed in work leagues or as an extension of the academic activities in the form of dissemination of work by students. Therefore, there are few activities, conducted by a few faculty members, which is to say that the work process of the faculty members do not incorporate this type of activity.

Although extension activities are part of the functions of the university, with the activities of teaching and research, they are not on an equal position in terms of institutional value, which unbalances the desired tripod of university functioning.

Recently, a movement of reframing of the concept of university extension has increased the traditional sense of diffusion and dissemination of knowledge to an educational, cultural and scientific process that articulates teaching and research with transforming potential(28).

One of the examples of programs that stimulate extension is the University Extension Program (PROEXT), with the purpose of supporting public HEls in the development of extension activities that promote greater interaction with the society. It is a program dedicated to public HEls, because in the private HEls, extension is the responsibility of the institutional context and its value depends on administrative management ${ }^{(28)}$.

Some experiences show that in private HEls, it is possible to develop extension activities with a positive impact on community healthcare. These studies share the understanding that extension activity is vital for strengthening the role of HEls in the training of professionals committed to the health of people ${ }^{(29-30)}$. This vision enables the development of teaching and learning processes from the everyday practices articulated with research, leading to the confrontation between theory and the real world. The operational difficulties are related to poor institutional value, expressed in forms of internal assessment that prioritize scientific production at the expense of other activities and, consequently, a low financial increment to perform them.

Regardless of the institutional format in which they are conducted, extension activities cannot be considered an extra to the training of students. They need to be considered as part of the teaching process,
Higher education in nursing: the faculty work process in different institutional contexts Leonello VM, Oliveira MAC 
and articulated with research. Particularly in nursing, extension activities are essential to formation and therefore the teaching practice, because without them, training is disconnected from the reality of the problems and health needs of the population.

\section{CONCLUSION}

It was observed that the faculty work process in three distinct contexts assumes formats with regard to organizational and didactic practices. However, as common characteristics, intensification and job insecurity were identified. Considering these results, it appears that there are many challenges to faculty work which unfold as questions, including: how can change processes in faculty work and, therefore, in practice, be triggered or initiated if the institutional context seems be given, immutable, and not subject to faculty interference? How is this reality to be faced without the action of the characters involved in it, especially the faculty members?

The answers to these challenges are complex. The improvement of structural conditions arising from a process of institutional restructuring, oriented more by educational policies towards the quality of higher education than for quantitative expansion of places in this area will positively impact the process of faculty work in different institutional contexts, and therefore quality of education and training. Such a change seems far from the current reality, which is increasingly grounded on market principles, with little appreciation of education, especially universal access to quality education.

However, it is a particular social and historical reality that, in a dialectical process, can also be rebuilt. For that, it is necessary to recognize that the social determinants of faculty work cannot preclude the search for coping strategies towards improvement of working conditions and teaching practices. Rather, it is essential that, through the analysis of this process, higher education faculty members in their different organizational and instructional practices can identify and understand problems and reflect about their work, giving new meaning to it and looking for new opportunities to rebuild their practice.

This process can be guaranteed by faculty professionalization, as long as it is not limited to the development of specific capabilities of the profession, but includes proposing alternatives that may promote better objective working conditions. Faculty professionalization is an ongoing process of training and reflection on professional practice. It takes into account the critical and reflective recognition about didactic practices, organizational practices, and their relation to the structural context of higher education.

This process of social change is complex and involves actions to challenge the reality of teaching, promoted by participation in unions, scientific and student organizations, a movement of resistance to a neoliberal proposal, resulting in precarious faculty work.

Recognizing the diversity of these formats in the faculty work context and practice enables higher education faculty members to be a heterogeneous group, which, although integrated in the same structural reality, perform under different working conditions. Faculty professionalization as a process of social change can be taken as a starting point for proposing coping strategies consistent with such a distinct reality of faculty work and practice.

\section{REFERENCES}

1. Martins CB. Reconfiguring higher education in Brazil: the participation of private institutions. Análise Soc (Lisboa). 2013;(208):622-58.

2. Brasil. Lei n. 9.394, de 20 de dezembro de 1996. Estabelece as diretrizes e bases da educação nacional. [Internet]. Brasília; 1996 [citado 2014 mar. 22]. Disponível em: http://www.planalto.gov.br/ccivil_03/leis/I9394.htm

3. Pimenta SG, Anastasiou LGC. Docência no ensino superior. São Paulo: Cortez; 2010.

4. Balbachevsky E. Academic careers in Brazil: the legacy of the past. J Prof. 2011;4(2):121-95.

5. Silvério MR, Patrício ZM, Brodbeck IM, Grosseman S. O ensino na área da saúde e sua repercussão na qualidade de vida docente. Rev Bras Educ Med. 2010;34(1):65-73.

6. Lemos MC, Passos JP. Satisfação e frustação no desempenho do trabalho docente em enfermagem. REME Rev Min Enferm. 2012;16(1):48-55.

7. Mendes-Gonçalves RB. Tecnologia e organização social das práticas de saúde. São Paulo: Hucitec; 1994.

8. Gimeno-Sacristán J. Consciência da ação sobre a prática como libertação profissional dos professores. In: Nóvoa A, organizador. Profissão professor. Porto: Porto Ed.; 1999. p. 92-63.

9. Balbachevsky E. Carreira e contexto institucional no sistema de ensino superior brasileiro. Sociologias (Porto Alegre). 2007;9(17):158-88.

10. Fiorin JL. Elementos da análise de discurso. 9a ed. São Paulo: Contexto; 2000. 
11. Lima KRS. O Banco Mundial e a educação superior brasileira na primeira década do novo século. Rev Katál (Florianópolis). $2011 ; 14(1): 86-94$.

12. Mancebo D. Trabalho docente na educação superior brasileira: mercantilização das relações e heteronomia acadêmica. Rev Port Educ. 2010;23(2):73-91.

13. Ferreira EM, Fernandes MFP, Prado C, Baptista PCP, Freitas GF, Bonini BB. Prazer e sofrimento no processo de trabalho do enfermeiro docente. Rev Esc Enferm USP. 2009;43(n.esp 2):1292-6.

14. Calderón Al. Terceirização do trabalho docente à luz da responsabilidade social da educação superior. Trab Educ Saúde. 2013;11(3):487-501.

15. Bexley E, James R, Arkoudis S. The Australian academic profession in transition: addressing the challenge of reconceptualising academic work and regenerating the academic workforce. Melbourne: Centre for the Study of Higher Education, The University of Melbourne, 2011.

16. Aguayo-Gonzales $M$, Monereo-Font $C$. The nurse teacher: construction of a new professional identity. Invest Educ Enferm. 2012;30(3):398-405.

17. Ribeiro MRR, Ciampone MHT. O debate acerca da complexidade dos objetos do trabalho docente na área de saúde. Educ Rev. 2008;9(2):51-64.

18. Haddad AE, Pierantoni CR, Ristoff D, organizadores. A trajetória dos cursos de graduação na área da saúde: $1991 \mathrm{e}$ 2004. Brasília: Instituto Nacional de Pesquisas Educacionais Estudos Anísio Teixeira; 2006. p. 142-68.

19. Rodrigues MTP, Mendes Sobrinho JAC. Obstáculos didáticos no cotidiano da prática pedagógica do enfermeiro professor. Rev Bras Enferm. 2008;61(4):440-35.

20. Fórum Nacional de Educação. Educação brasileira: indicadores e desafios: documentos de consulta [Internet]. Brasília: Ministério da Educação; 2013 [citado 2014 set. 26]. Disponível em: http://conae2014.mec.gov.br/images/pdf/ educacao_brasileira_indicadores_e_desafios.pdf

21. Brenneman MW, Callan PM, Ewell PT, Finney JE, Jones DP, Zis S. Good Policy, Good Practice II. Improving outcomes and productivity in higher education: a guide for policymakers: a Joint Report from The National Center for Public Policy and Higher Education and The National Center for Higher Education Management Systems [Internet]. Boulder, Colorado; 2010 [cited 2014 Jan 10]. Available from: http://www.highereducation.org/reports/Policy_Practice_2010/GPGPII.pdf
22. Schwartzman J, Schwartzman S. O ensino superior privado como setor econômico [Internet]. Brasília; 2002 [citado 2012 maio 05]. Disponível em: http://biblioteca.planejamento.gov. br/biblioteca-tematica-1/textos/educacao-cultura/texto-982013-o-ensino-superior-privado-como-setor-economico.pdf

23. European Trade Union Committee for Education; Committee Syndical European de L'Education. Teacher education in Europe: an ETUCE policy paper [Internet]. 2008 [cited 2014 Jan 10]. Available from: http://etuce.homestead.com/Publications2008/ETUCE_PolicyPaper_en_web.pdf

24. Coordenadoria de Aperfeiçoamento de Pessoal de Nível Superior. Critérios de Avaliação Trienal. Triênio avaliado: 20042007 [Internet]. Brasília: CAPES; 2008 [citado 2012 jun. 18]. Disponível em: http://www.capes.gov.br/images/stories/ download/avaliacao/CA2007_CienciasSaude.pdf

25. Bosi MLM. Produtivismo e avaliação acadêmica na saúde coletiva brasileira: desafios para a pesquisa em Ciências Humanas e Sociais. Cad Saúde Pública. 2012;28(12):2387-92.

26. Silva Junior JR, Ferreira LR, Kato FBG. Trabalho do professor pesquisador diante da expansão da pós-graduação no Brasil pós-LDB. Rev Bras Educ. 2013;18(53):435-56.

27. High Level Group on the Modernisation of Higher Education. Report to the European Commission on improving the quality of teaching and learning in Europe's higher education institutions [Internet]. 2013 [cited 2014 Jan 10]. Available from: http://ec.europa.eu/education/higher-education/doc/modernisation_en.pdf

28. Brasil. Decreto n. 6.495 , de 30 de junho de 2008. Institui o Programa de Extensão Universitária - PROEXT [Internet]. Brasília; 2008 [citado 2014 set. 26]. Disponível em: http:// www.planalto.gov.br/ccivil_03/_Ato2007-2010/2008/Decreto/D6495.htm

29. Hennington EA. Acolhimento como prática interdisciplinar num programa de extensão universitária. Cad Saúde Pública. 2005;21(1):256-65.

30. Ilha S, Zamberlan C, Gehlen MH, Dias MV, Nicola GDO, Backes DS. Qualidade de vida do familiar cuidador de idosos com Alzheimer: contribuição de um projeto de extensão. Cogitare Enferm. 2012;17(2):270-6.
Correspondence addressed to: Valéria Marli Leonello

Departamento de Orientação Profissional, Escola de Enfermagem da USP Av. Dr. Enéas de Carvalho Aguiar, 419 - Cerqueira Cesar CEP 05403-000 - São Paulo, SP, Brazil

E-mail: valeria.leonello@usp.br 